\title{
A Preliminary Risk Assessment on the Development of a Small-scaled Floating Power Plant
}

\author{
Sung-In Park \\ a) Dep't. of Naval Architecture and Ocean Engineering, Pusan National University \\ 2, Busandaehak-ro 63beon-gil, Geumjeong-gu, Busan 46241, Republic of Korea \\ ${ }^{b)}$ System Safety Research Dep't., Korea Ship \& Offshore Engineering Co., Ltd. \\ 55, Bundang-ro, Bundang-gu, Seongnam-si, Gyeonggi-do 13591, Republic of Korea \\ parksungin@pusan.ac.kr
}

\section{Su Kyeong Kim}

a) Dep't. of Naval Architecture and Ocean Engineering, Pusan National University 2, Busandaehak-ro 63beon-gil, Geumjeong-gu, Busan 46241, Republic of Korea kimsukyeong@pusan.ac.kr

\section{Sang Jin Kim ${ }^{1}$}

c) The Korea Ship and Offshore Research Institute, Pusan National University 2, Busandaehak-ro 63beon-gil, Geumjeong-gu, Busan 46241, Republic of Korea sangjin@pusan.ac.kr

\section{Jeom Kee Paik}

a) Dep't. of Naval Architecture and Ocean Engineering, Pusan National University 2, Busandaehak-ro 63beon-gil, Geumjeong-gu, Busan 46241, Republic of Korea ${ }^{c}$ The Korea Ship and Offshore Research Institute (Lloyd's Register Foundation Research Centre of Excellence), Pusan National University

2, Busandaehak-ro 63beon-gil, Geumjeong-gu, Busan 46241, Republic of Korea d) Dep't. of Mechanical Engineering, University College London London, WC1E 7JE, United Kingdom jeompaik@gmail.com

\footnotetext{
${ }^{1}$ Corresponding author.
} 
Journal of Offshore Mechanics and Arctic Engineering

\section{ABSTRACT}

This paper introduces a preliminary risk assessment carried out on a newly developed floating power plant. The small-scale floating power plant has been developed to provide electric power for areas on demand, and this is a kind of a new concept system which is not clearly classified in the maritime industry. To grant the feasibility on this novel system design, a set of risk assessment activities is essentially required and in this context a hazard identification (HAZID) study is conducted at the very early stage of the plant design. The aims of this HAZID study are to verify the inherent safety of the initial plant design and to provide any recommendations on the next design stages. For this purpose, the potential hazards are identified in view of personnel, structural and asset effects in association with the operation of the power plant and all identified hazards and relevant risks are assessed with defined criteria using a simple risk matrix. As the results, the risk or safety level of the conceptual plant design is estimated and some design changes are suggested to give a better balance between the safety and the cost of the plant system. Overall this paper shows how the primitive risk assessment techniques are utilized as a practical engineering tool on the development of the marine system.

OMAE-19-1002, Kim, 2 


\section{INTRODUCTION}

In recent years, various floating type power plant concepts have been popped up as an alternative to power supply systems in the world [1-3]. Although the floating system has many disadvantages in comparison with the traditional onshore systems, it takes unique strengths with its mobility and floatability and these characteristics make its effective application all around the world. In compliance with this trend, a smallscaled floating power plant system has been developed as the energy solution to areas suffering from a lack of electricity. This small-scaled plant seems to be more efficient system targeting group of islands around Southeast Asia which make a large floating system difficult to approach. The operational concept of this plant system is 1) receiving liquefied natural gas (LNG) from a bunkering vessel; 2) storing LNG in a cargo tank space and vaporizing it as natural gas (NG); and 3) generating and transferring electric power to an area on demand (Fig. 1).

Because this is a kind of the new system, which is not clearly classified structures in any maritime rules and regulations, a set of risk assessment studies is essentially required for its qualified design [4]. In accordance with this, authoritative maritime classification societies provide the recommended guidelines for the development of a novel concept design [5-7] and Fig. 2 shows the general design approval process of the classification society over the development phases of a marine system [5].

Among the overall process in Fig. 2, this paper introduces a preliminary risk assessment study conducted at the conceptual design phase of the plant development. 
Journal of Offshore Mechanics and Arctic Engineering

At the very early stage of the plant design, the concept idea is actualized into the initial design based on the general guidelines and requirements of similar systems such as a commercial LNG carrier and on \& offshore plant facilities. Unlike existing systems, this novel concept may take particular risks by nature and these need to be identified and addressed through a set of risk assessment studies. In regard to this, guidelines of classification societies recommend conducting a hazard identification (HAZID) study as an appropriate application at the early design stage [5-7]. The HAZID is a kind of a quantitative risk assessment technique to identify potential hazards or associated risks that could arise from a target system. These hazards are typically related to the safety or damage of personnel, asset and environment during a system operation. With respect to above issues, the HAZID and relevant simple risk assessment studies are carried out in order to make the small-scale floating power plant concept more feasible so as to grant the approval in principle (AIP) on its conceptual design from an authorized classification society. This paper summarizes all relevant works to the preliminary risk assessment activities along with the basic engineering output of the plant system development.

\section{DESIGN BASIS OF FLOATING POWER PLANT}

The concept idea of the floating power plant comes from a combination of a non-self-propelled barge and a small-scale LNG power plant. As like a typical floating structure, this system is largely divided into two parts which are hull and topside structures. The hull structure consists of a pressure vessel for the LNG storage, ballast, 
Journal of Offshore Mechanics and Arctic Engineering

void and other miscellaneous tank spaces and machinery rooms for utility functions of the plant operation. The topside mainly consists of a process area including regasification systems associated with boil-off gas (BOG) handling, a power generation area with a set of power generation engines and an accommodation block for service areas. The target power generation rate is about 10-20 MWh and this can be achieved with a set of engines and the re-gasification unit capacity of 8.2 MMSCFD. An expected production rate is USD 0.076 per kWh using LNG fuel and this is less than half of the production rate using diesel fuel for electricity power generation (about USD 0.13 per kWh assuming USD 704 per metric ton of diesel oil). Table 1 indicates the approximated principal dimensions of the plant hull structure and Fig. 3 shows the general arrangement of the overall plant layout design.

Based on the design guidance for typical ship and on \& offshore plant systems, special considerations have been added for the basic engineering of this integrated floating system. Because this plant operation is closely related to hydrocarbon ( $\mathrm{HC})$ process, the design of the floating power plant should consider the inherent safety against flammable leak and derived fire and explosion accidents. For this purpose, the overall plant layout is separated into several hazardous and fire zone divisions.

A hazardous zone (or area) is all those areas in which explosive gas or air mixture may normally be expected to be present in quantities which can require special precautions for the construction and use of electrical equipment and machinery. This is divided into three zones depending upon the grade of release [8];

OMAE-19-1002, Kim, 5 
- Zone 0: in which an explosive gas atmosphere is continuously present or present for long periods;

- Zone 1: in which an explosive gas atmosphere is likely to occur in normal operation;

- Zone 2: in which an explosive gas atmosphere is not likely to occur in normal operation, and if it does occur, is likely to do so infrequently and will exist for a short period only.

A fire zone is an area within the plant where equipment is grouped by its nature and similar level of risk. The separation of the plant into several fire zones means that possible flammable leak, fire and explosion events in the concerned fire zone do not impact other zones. The fire zone definition is closely connected with the integrated control and safety system (ICSS) in the plant such as emergency shut-down (ESD) and a deluge system. Based on well verified hazardous and fire zone layouts, the plant facility can take the inherent fire safety in its design. Figures 4 and 5 show the developed hazardous and fire zone layouts of the plant system.

Figure 6 shows the conceptual process flow of the floating power plant. The transferred and stored LNG is supplied into the main power generator via two routes which are: 1) LNG feed pump - vaporizer \& heater - generator; and 2) BOG line - BOG compressor package - generator.

\section{RISK ASSESSMENT STUDY}

OMAE-19-1002, Kim, 6 
Journal of Offshore Mechanics and Arctic Engineering

Without any specific rules and regulations for this plant system design, a set of risk assessment activities should be conducted through all life-cycle of the system and this can manage the risk level of the plant system as low as reasonably practicable (ALARP). In regard to this, the International Maritime Organization (IMO) which is the special organization in the maritime industry introduces the formal safety assessment (FSA) and recommends to apply it for the evaluation works relevant to the maritime system development [4].

Figure 7 shows the flow chart of the FSA. Firstly, all potential hazards related to a target development system are identified and associated risk levels are assessed with risk control measures applied in the design. Based on evaluated risk levels, the project decision maker may require additional control measures or keep the current design state with consideration of the cost-benefit aspect. This process flow can be repeated several times based on the development phase and the complexity of the system. Generally, a simple and qualitative assessment approach is selected for the application on the early design stage and with the design progress, more and more detail and quantitative approaches can be applied.

\subsection{HAZID Objective and Scope}

At the current stage of the floating power plant development, not many detail specifications of system components are defined yet, i.e., the conceptual plant design is comprised of the process flow diagrams (PFDs) and the general layout plan rather than 
Journal of Offshore Mechanics and Arctic Engineering

the piping instrument diagrams (PIDs) and any detail equipment layout and structural scantling. Therefore, as the first step of the FSA, the HAZID study is carried out and identified risks are assessed using a simple risk matrix regarding to the safety of working personnel and the plant system. The objective of this activity is to verify the critical issue and the safety level of the current plant design, to suggest recommendations on design improvement and to utilize it as an intuitive information for more detail safety studies during the front-end engineering design (FEED) stage of the plant design.

This HAZID is mainly focused on the plant main operation process, i.e., LNG bunkering and normal site operations and thereby any other development phases such as construction, transportation and installation are excluded from the scope of the work. The bunkering operation is considered as 6 stages with combined operations between a bunkering vessel and the floating plant such as 1) berthing; 2) hose connecting; 3) drying; 4) inerting; 5) cool-down; and 6) LNG transferring. For the normal operation, the process flow from the LNG cargo tank to the power generator is chased based on divided system node sections. Table 2 indicates the target operation modes of the HAZID session. In addition, a drawback of the initial plant design is analyzed with the plant general layout drawing.

\subsection{HAZID Methodology}

The HAZID is a workshop-based study carried out by a team of multi-discipline personnel. For the objectivity and reliability on its result, a HAZID team generally requires a project independent safety engineer to be participated as a facilitator or one of participants [4, 
Journal of Offshore Mechanics and Arctic Engineering

9]. However, the HAZID team for this study consists of all project relevant engineers because of the study characteristic, which is a preliminary engineering review for the developed conceptual plant design and the preparation of the AIP process.

Various techniques can be applied for identifying hazards and assessing linked risk levels with the characteristics of a target system [4, 9] and a HAZID* is selected as the proper technique for this HAZID study. The HAZID* uses a set of guidewords to encourage creative thinking of possible hazards related to a target system. Based on guided hazard categories, participants discuss potential causes and derived consequences of hazardous events or accidental events. As an example of the typical guidewords, the IMO and the Centre for Marine and Petroleum Technology (CMPT) introduce general lists related to ship and offshore facilities [4, 9] and the integrated project of the European maritime industry presented representative hazards in a LNG carrier ship operation through its research report [10].

Based on above reference documents, a set of hazard guidewords has been carefully selected and its suitability is discussed with team members before the HAZID session commencement. Table 3 indicates the derived hazard guidewords.

\subsection{Risk Assessment Criteria}

After the identification of possible hazards or associated accidents, their risk levels are calculated and assessed with pre-defined criteria. The IMO introduces the risk as the combination of frequency and consequence of the considered accidental event [4] and this is typically expressed as the multiplication form in the quantitative risk assessment 
Journal of Offshore Mechanics and Arctic Engineering

study [9]. However, in some cases, the risk is presented as the summation form using log-scaled or uniquely defined frequency and consequence indices for the practical application and this approach is especially preferred in the simple study, e.g. qualitative or semi-quantitative risk assessment studies [10].

The purpose of this study is to verify and to rank all possible hazardous events of the plant operation at the very early design stage and thereby the risk is defined as the summation of log-scaled frequency and specific consequence indices for convenience of the process. Then, the risk finally is estimated using a risk matrix (Table 4) and this is assessed with the ALARP criteria which refers to a level of risk as negligible, conditionally acceptable or intolerable.

In regard to the acceptable risk level, the UK Health and Safety Executive (UK HSE) which is a one of the most authoritative organizations for the industrial safety suggests the acceptable boundaries as the individual risk (IR) of $10^{-3}$ or $10^{-4}$ per year for the maximum tolerable risk (for working personnel and public group, each) and the IR of $10^{-6}$ per year for the broadly acceptable risk [11]. Also, the CMPT introduces the application of major oil companies as the IR value of $10^{-2}$ or $10^{-3}$ per year for the upper acceptable limitation [9]. Here, the IR represents the fatal risk of a single individual at the specific location of a facility $[4,9,11]$.

For the development of the floating LNG power plant, the acceptable risk limit is set around $10^{-4}$ per year of the personal fatality and Fig. 8 presents the applied ALARP criteria consisting of negligible (acceptable), conditionally acceptable and intolerable (not acceptable) risk ranges in this preliminary risk assessment study. 
Journal of Offshore Mechanics and Arctic Engineering

Tables 5 and 6 show defined risk indices for the simple expression of the accident consequence and frequency in this HAZID study. Those are specified with the discussion between participants before the HAZID session and the asset impact is decided with consideration of the expected electricity generation cost of the floating power plant (about USD 150,000 per week). It is worthwhile to note that when a hazard results in several consequence categories (personnel, structure and asset, refer to Table 5), the most severe one should be considered as the consequence index for the risk calculation. For example, if one event which takes a specific frequency is possible to derive a single fatality, major equipment damage and asset impact less than USD 150,000, then the single fatality is selected as the consequence index for the risk calculation.

\section{RESULT AND DISCUSSION}

As the results of the HAZID study, total 51 hazardous events were identified and these came from the LNG bunkering operation (24) and the plant normal operation (27) respectively. In regard to the general layout design of the floating power plant, 4 considerations were suggested.

Among all identified hazards relevant to the plant operation, 35 were assessed as negligible, 14 were assessed as conditionally acceptable and only 2 were assessed as intolerable risk levels. Figure 9 shows evaluated risk levels relevant to the plant operational modes (Table 2) of the floating power plant. 
Journal of Offshore Mechanics and Arctic Engineering

\subsection{General Layout Design of the Floating Power Plant}

In regard to the general design concept of the plant, 4 inherent weak points were suggested and discussed during the HAZID session.

The first and the most critical issue was related to a natural disaster of an expected plant location. This small-scale floating power plant has been developed targeting its application area around Southeast Asia. A preliminary project investigation verified that several specific target locations normally have a stable atmospheric and sea condition all the over year. However, there is growing concern about a disaster such as earthquake and tsunami in relevant areas and these events could lead to an overall shutdown or total loss of this small-scale floating system. Even if this category is considered as a very rare event in a general probabilistic risk assessment, tragic disasters over the last two decades $[12,13]$ could make it possible scenario around the target area location and a need for the design consideration.

Other three issues were all relevant to the general layout design of the plant; 1) too low sea chest location concerning alien substance flow into sea chest, 2) opening of the escape route near the process area concerning a direct fire exposure and 3) cryogenic protection on process pipping lines. The last item was immediately updated on the general layout design and regarded as an existing safety measure of the floating power plant. The rest was agreed to be discussed in more detail at the next design stage.

\subsection{LNG Bunkering Operation of the Floating Power Plant}

OMAE-19-1002, Kim, 12 
Journal of Offshore Mechanics and Arctic Engineering

As the result of the HAZID session on the LNG bunkering operation, 2, 11 and 11 hazards were evaluated as intolerable, conditionally acceptable and negligible risks respectively. By sorting this in the category of the hazard guidewords, the structural impact hazard (8) was followed by operational (7), process system (4), system failure (3), environmental (1) and fire \& explosion (1) (Fig. 10). When looking into details, most of hazards which were assessed as not negligible stemmed from mis-operation works during the bunkering. The HAZID session identified the operational hazard due to human error as the second largest number of the hazard category and also it diagnosed that many hazards in different hazard categories could be generated by operational mistakes over all working stages such as miscommunication, misbehavior, equipment mishandling of working personnel. Interestingly, there was no expert for the site operation in the HAZID team and all members consisted of engineers developing the plant system. Most of participants tended to overestimate the risk indices giving high frequency or severe consequence but at the same time they agreed that all operational hazards could be managed by a well-established site working procedure rather than any specific safety system in the plant.

Verified existing safety measures and suggested recommendations during the HAZID session back up the above assumption by emphasizing the need for an operational guideline or manual for the plant operation (Fig. 11). In regard to identified hazards in other categories, it was expected that the existing safety system or additional measures could effectively prevent or manage their risk level. Figure 11 shows the part of the 
Journal of Offshore Mechanics and Arctic Engineering

HAZID worksheet which categorizes hazards and ranks associated risks over the conditionally acceptable level relevant to the LNG bunkering operation.

\subsection{Normal Operation of the Floating Power Plant}

This HAZID session mainly focused on the process flow of the power plant operation. Therefore, most of hazards were inferred from a consideration of the abnormal process condition. As the result, the majority of identified hazards were evaluated as negligible risks except for 3 conditionally acceptable risks (Fig. 12).

In this session, most hazards were considered with connection to the mechanical failure of safety, utility and process systems but all participants expected that those could be prevented with existing safety barriers and redundancy designs of the plant. When the HAZID team talked about the problem of the process flow, there were always existing safety instrumented system (SIS) at considered flow lines and these were anticipated to safely control the abnormal process condition such as high or low pressure, temperature and flow conditions.

Here is a key point of this risk assessment study. The process PIDs of the floating power plant has been drawn when the HAZID session was made and here, several control logic and valve systems which had existed in the PFDs were decided to be removed from the process flow lines. This means that the plant system was initially designed with a plethora of process safety systems and their quantities can be reduced in the boundary of the minimum safety level for the project cost management aspect. In fact, with the completed basic engineering output, the construction cost of the floating power plant 
Journal of Offshore Mechanics and Arctic Engineering

was roughly estimated and this concluded a need for the cost reduction measure throughout all engineering items. The result of this HAZID session which presented the well acceptable risk level of the plant normal operation supports above situation.

Figure 13 shows the part of the HAZID worksheet which categorizes hazards and ranks associated risks over the conditionally acceptable level relevant to the plant normal operation.

\section{CONCLUSIONS}

In this paper, the HAZID and relevant risk assessment study on the newly developed small scale floating power plant has been introduced. It identified various hazards relevant to the plant operation and most of them were reviewed as a negligible risk and some hazards were assessed as conditionally acceptable and intolerable risk levels. As the result, the safety level of the current plant design was verified and this pointed out a need for some additional safety measures and the removal of safety systems at the same time.

Just a higher safety or a lower cost does not guarantee the satisfactory system design but both elements should be harmonized. In this regard, performing a proper set of risk assessment activities encourages a well-balanced system design between the safety and the cost management of the project. The preliminary risk assessment on the floating power plant played a role as the effective engineering review work and it enabled the plant system to achieve the AIP certification in its conceptual design. 
Journal of Offshore Mechanics and Arctic Engineering

Moreover, the result of this study is to be utilized as input for further detail safety

studies in later design stages and this will lead to the more robust design of the floating power plant.

ACKNOWLEDGMENT

OMAE-19-1002, Kim, 16 
Journal of Offshore Mechanics and Arctic Engineering

\section{NOMENCLATURE}

kWh kilo- watt-hour

MMSCFD million metric standard cubic feet per day

MWh mega-watt-hour

USD United States dollar

OMAE-19-1002, Kim, 17 
Journal of Offshore Mechanics and Arctic Engineering

\section{REFERENCES}

[1] Forester Media. “DSME Displayed Floating Power Plant at Power-Gen International in Orlando Last December". Forester Media, January 10, 2015.

http://foresternetwork.com/weekly/distributed-energy-weekly/energy/dsme-

displayed-floating-power-plants-at-power-gen-international-in-orlando-last-december.

[2] Riviera Newsdesk. "LNG News: LNG Industry Poised to Adopt Floating Power Plants". Riviera - LNG World Shipping, January 09, 2018.

http://www.Ingworldshipping.com/news/view,Ing-industry-poised-to-adopt-floatingpower-plants_50389.htm.

[3] Wison Company News. "Wison Offshore \& Marine's 300MW FSRP Receives Approval in Principle from Lloyd's Register". Wison, September 19, 2018.

http://www.wison.com/en/read_page/951.

[4] IMO, 2015, "MSC-MEPC.2/Circ.12/Rev.1: Revised Guidelines for Formal Safety Assessment (FSA) for Use in the IMO Rule-making Process", International Maritime Organization, London, UK.

[5] ABS, 2017, "Guidance Notes on Review and Approval of Novel Concepts", American Bureau of Shipping, TX, USA.

[6] DNV·GL, 2017, “Recommended Practice-A203: Technology Qualification”, Det Norske Veritas and Germanischer Lloyd, Oslo, Norway.

[7] LR, 2017, “Guidance Notes for Technology Qualification”, Lloyd's Register, London.

[8] DNV·GL, 2017, "Offshore Standards-A101: Safety Principles and Arrangements", Det Norske Veritas and Germanischer Lloyd, Oslo, Norway.

[9] CMPT, 1999, "A Guide to Quantitative Risk Assessment for Offshore Installations", The Centre for Marine and Petroleum Technology, Bristol, UK.

[10] SAFEDOR, 2005, "HAZID for LNG Tankers", Document ID: SAFEDOR-D-4.3.1-200511-29-LMG-HAZID LNG Tankers-rev-03, SAFEDOR Consortium, European Commission.

[11] HSE, 1992, "The Tolerability of Risk from Nuclear Power Stations", Health and Safety Executive, London, UK.

[12] Rodgers, Lucy and Fletcher, Gerry. "Indian Ocean tsunami: Then and now". BBC, December 25, 2014.

https://www.bbc.com/news/world-asia-30034501.

OMAE-19-1002, Kim, 18 
Journal of Offshore Mechanics and Arctic Engineering

[13] Clarke, Hilary and Almasy, Steve. "Tsunami in Indonesia kills at least 222 without warning". CNN, December 23, 2018.

https://edition.cnn.com/2018/12/22/asia/deadly-tsunami-indonesia/index.html.

OMAE-19-1002, Kim, 19 
Journal of Offshore Mechanics and Arctic Engineering

\section{Figure Captions List}

Fig. 1 Concept of the floating power plant operation

Fig. 2 General design approval process of the classification society

Fig. 3 General arrangement of the floating power plant

Fig. $4 \quad$ Hazardous zone layout of the floating power plant

Fig. 5 Fire zone layout of the floating power plant (profile view)

Fig. $6 \quad$ Conceptual flow diagram of the floating power plant

Fig. $7 \quad$ Flow chart of the formal safety assessment methodology

Fig. 8 ALARP criteria for the risk evaluation in the HAZID study

Fig. 9 Evaluated risk level of identified hazards relevant to the plant operation modes

Fig. 10 Detail categorized hazards and risk levels relevant to the LNG bunkering operation

Fig. 11 Categorized and ranked HAZID worksheet relevant to the LNG bunkering operation

Fig. 12 Detail categorized hazards and risk levels relevant to the plant normal operation

Fig. 13 Categorized and ranked HAZID worksheet relevant to the plant normal operation 
Journal of Offshore Mechanics and Arctic Engineering

\section{Table Caption List}

Table 1 Principal dimension of the floating power plant hull structure

Table 2 Detail target operation modes of each HAZID session

Table 3 Guideword lists of the HAZID study

Table 4 Risk matrix for evaluation and ranking of the risk level in the HAZID study

Table 5 Consequence indices of the HAZID study

Table 6 Frequency indices of the HAZID study 


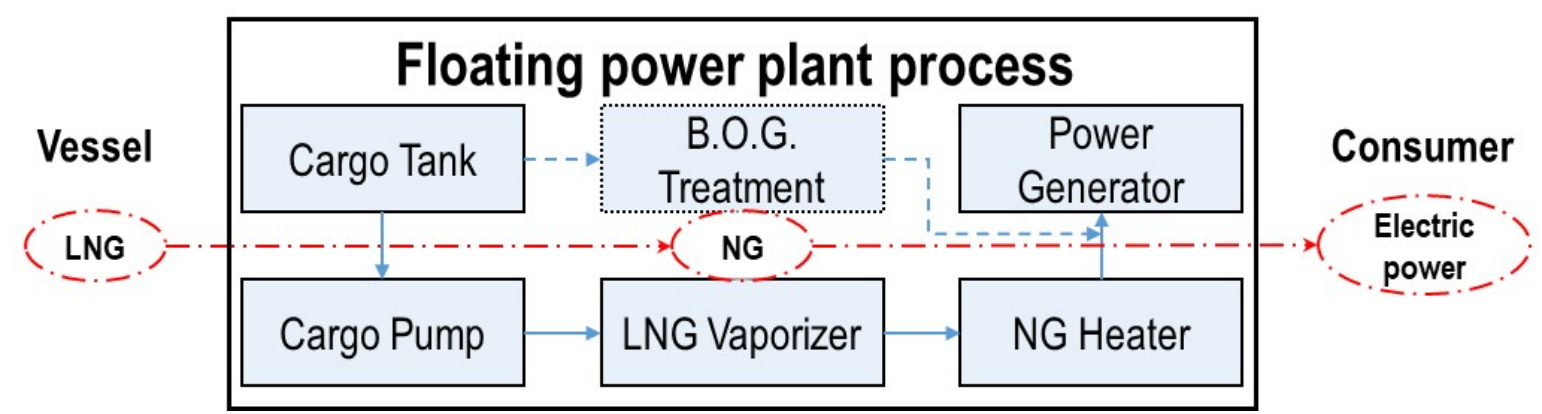

Fig. 1 Concept of the floating power plant operation 
Journal of Offshore Mechanics and Arctic Engineering

\begin{tabular}{|c|c|c|c|c|}
\hline $\begin{array}{c}\text { Feasibilityl } \\
\text { Conceptual Design }\end{array}$ & $\begin{array}{c}\text { Front-End } \\
\text { Engineering Design }\end{array}$ & Detailed Design & Construction & Operation \\
\hline $\begin{array}{c}\text { Approval in } \\
\text { Principle }\end{array}$ & $\begin{array}{c}\text { "Concept Feasible" } \\
\text { "Concept Verified" }\end{array}$ & $\begin{array}{c}\text { Final Class } \\
\text { Approval }\end{array}$ \\
\hline
\end{tabular}

Fig. 2 General design approval process of the classification society

OMAE-19-1002, Kim, 23 
Journal of Offshore Mechanics and Arctic Engineering

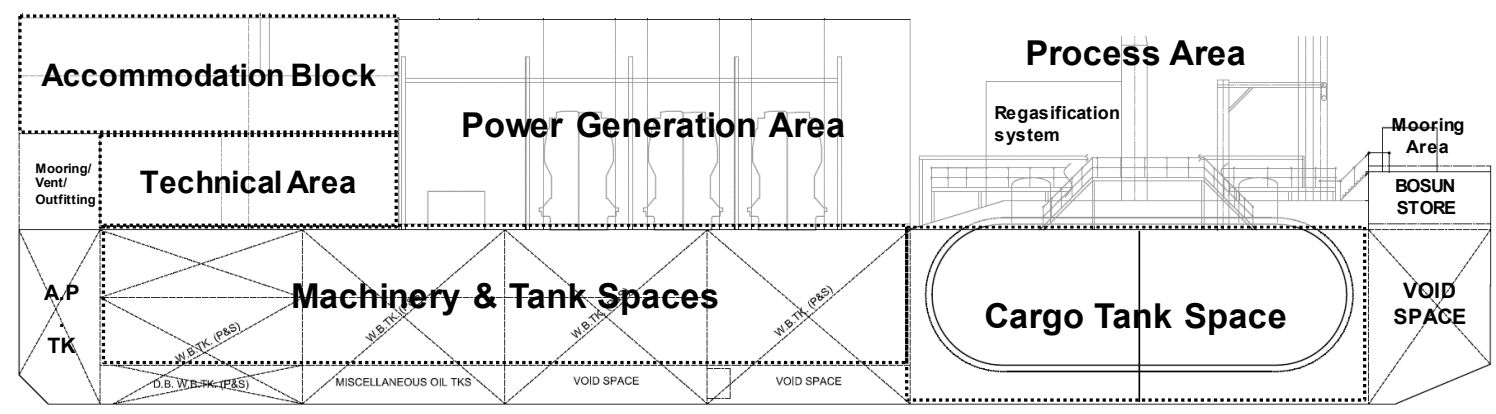

(a) Profile view

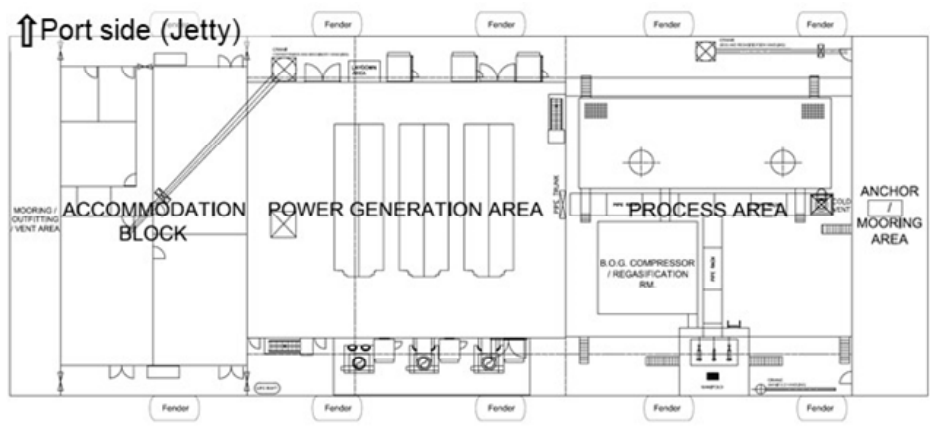

(b) Upper deck plan

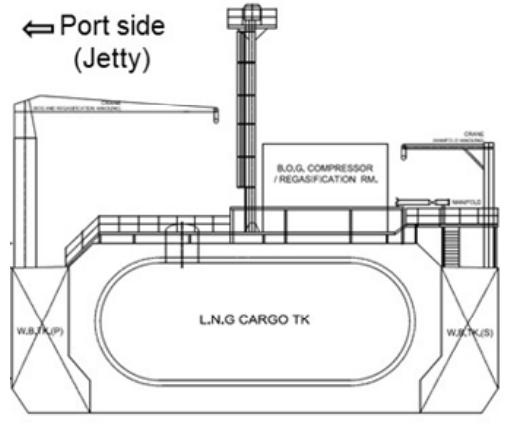

(c) Midship section plan

Fig. 3 General arrangement of the floating power plant 
Journal of Offshore Mechanics and Arctic Engineering

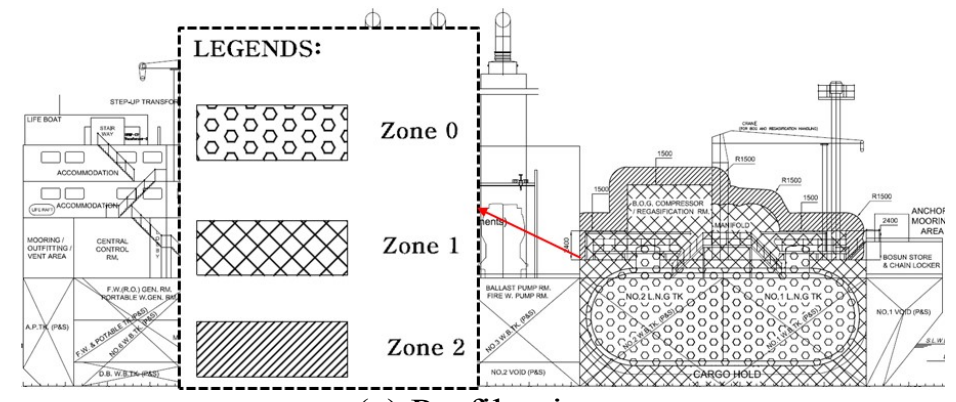

(a) Profile view

Fig. 4 Hazardous zone layout of the floating power plant

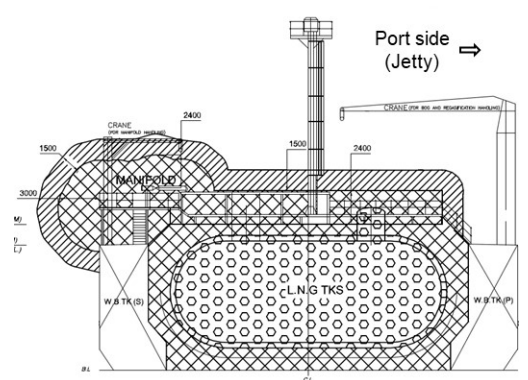

(b) Midship section plan

OMAE-19-1002, Kim, 25 
Journal of Offshore Mechanics and Arctic Engineering

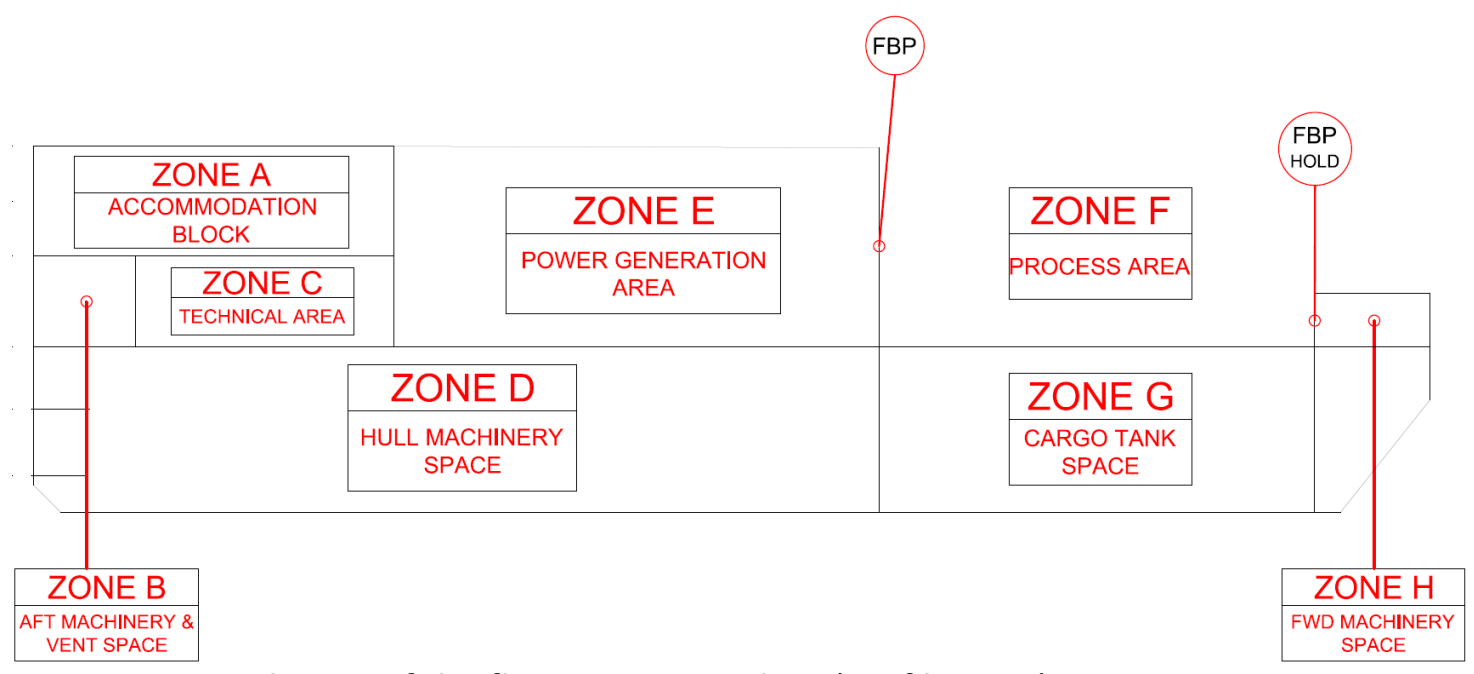

Fig. 5 Fire zone layout of the floating power plant (profile view)

OMAE-19-1002, Kim, 26 
Journal of Offshore Mechanics and Arctic Engineering

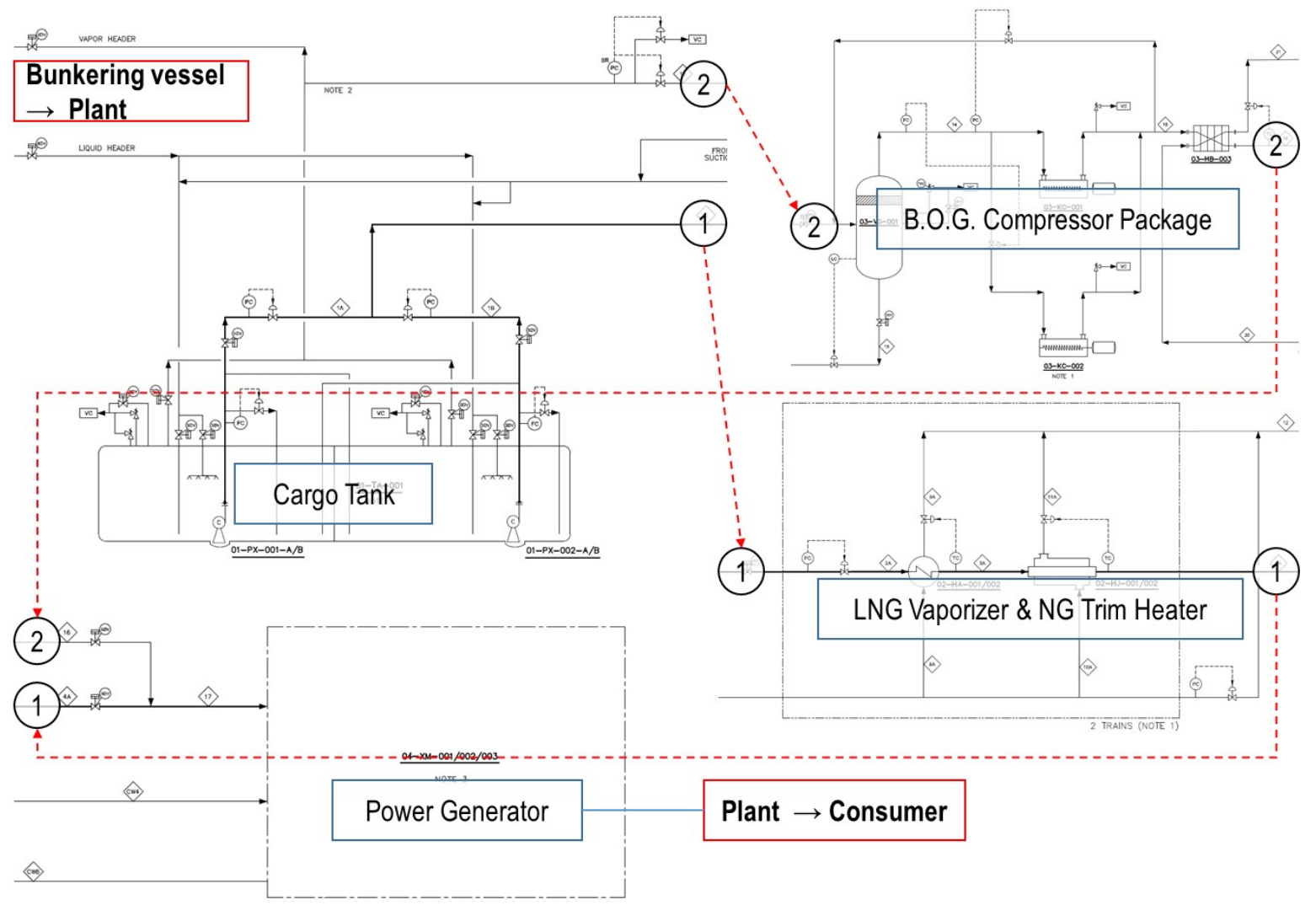

Fig. 6 Conceptual flow diagram of the floating power plant

OMAE-19-1002, Kim, 27 
Journal of Offshore Mechanics and Arctic Engineering

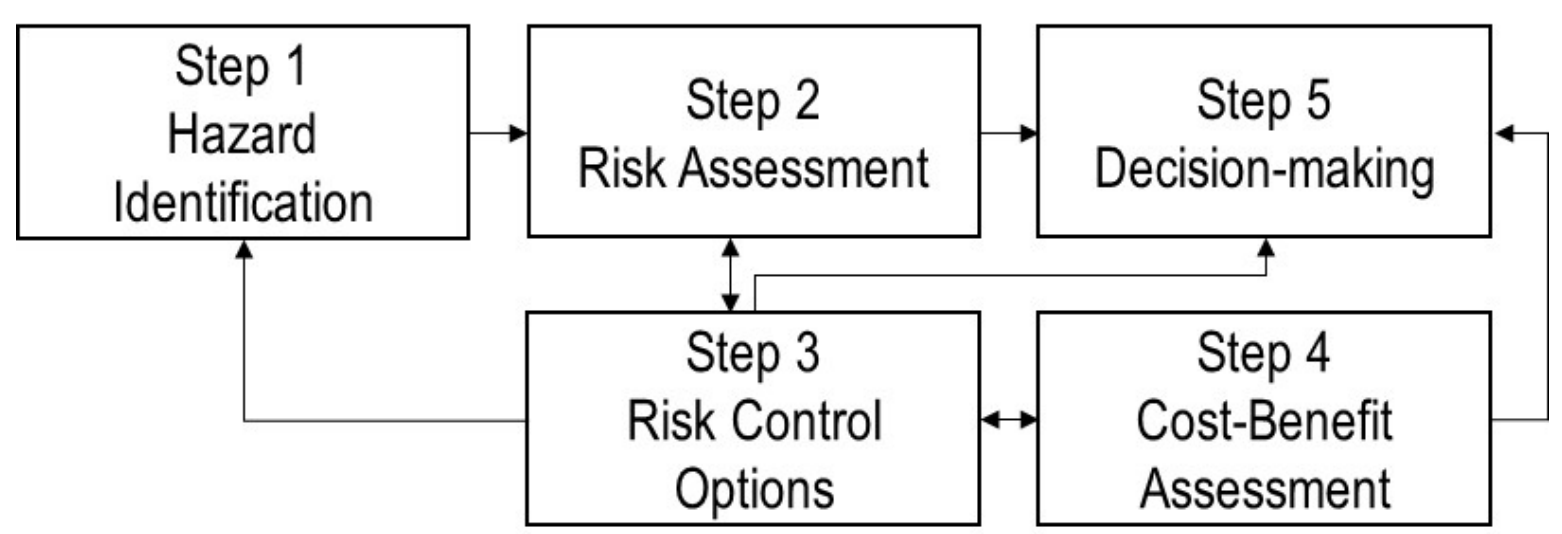

Fig. 7 Flow chart of the formal safety assessment methodology 
Journal of Offshore Mechanics and Arctic Engineering

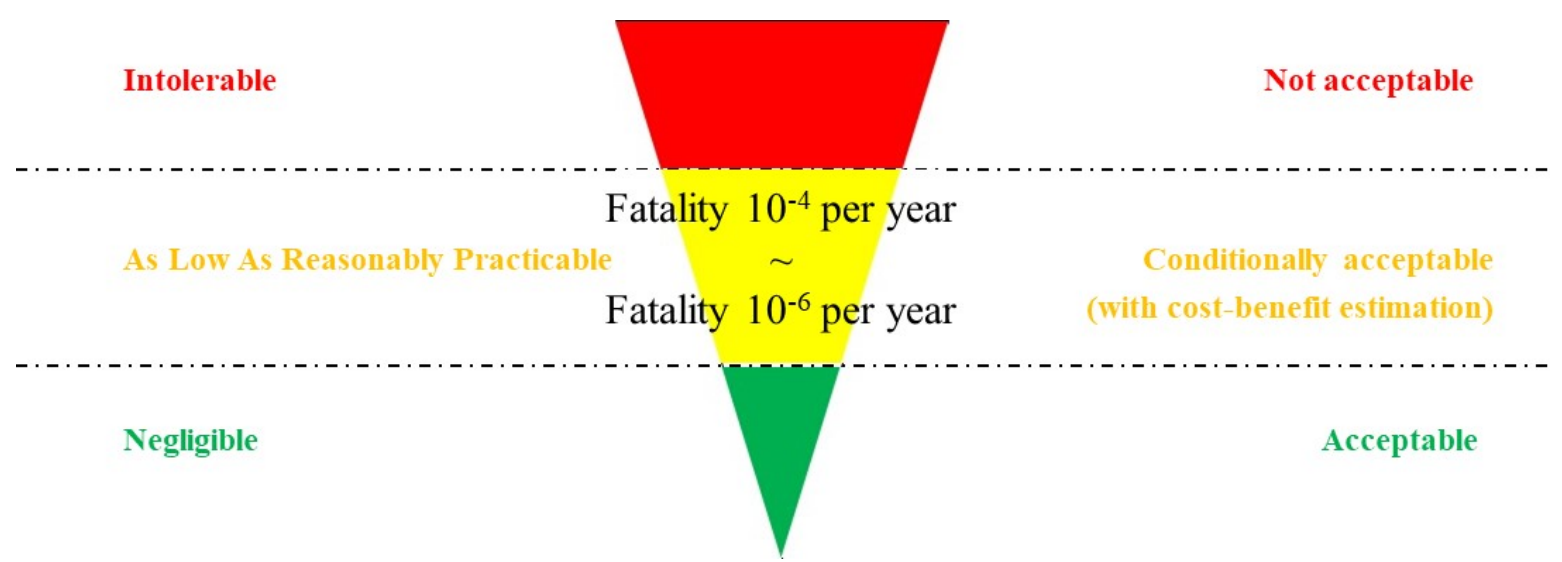

Fig. 8 ALARP criteria for the risk evaluation in the HAZID study

OMAE-19-1002, Kim, 29 
Journal of Offshore Mechanics and Arctic Engineering
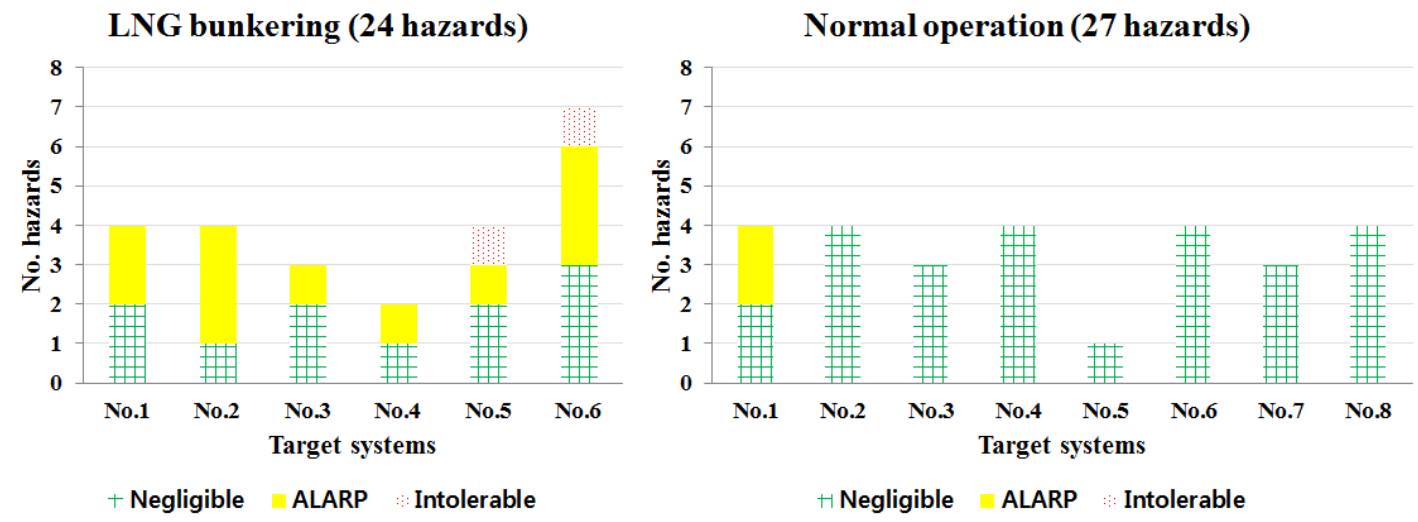

Fig. 9 Evaluated risk level of identified hazards relevant to the plant operation modes

OMAE-19-1002, Kim, 30 


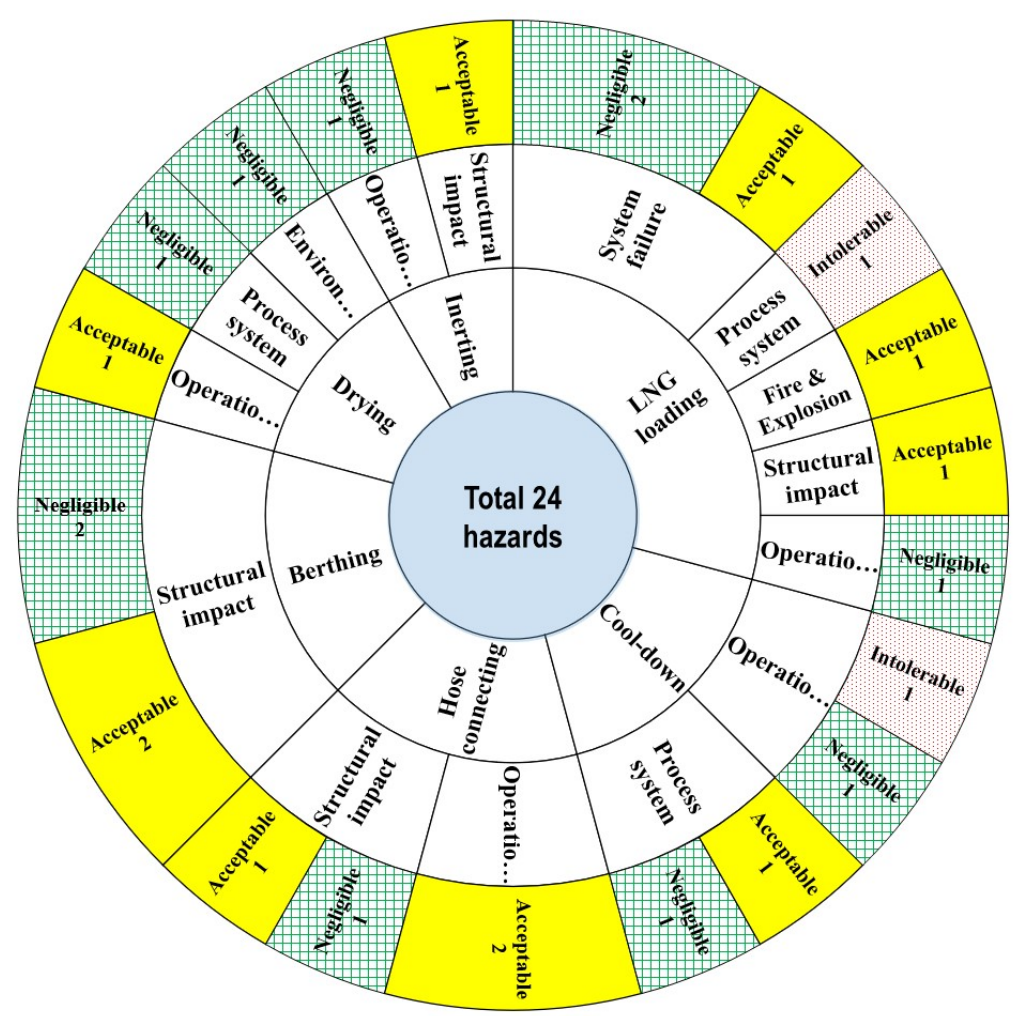

\#\#\#\# Negligible risk Conditionally acceptable risk Intolerable risk

Structural impact (8)

- Collision between a bunkering vessel and the plant

- Dropped-object during hose connecting

- Mooring line failure

Operational (7)

- Human error relevant to each operation

\section{Process system (4)}

- Tank overpressure and release of inventory during the operation

System failure (3)

- Any utility and measurement system failure

Environmental (1)

- Harsh weather condition

Fire \& Explosion (1)

- External fire from a bunkering vessel

Fig. 10 Detail categorized hazards and risk levels relevant to the LNG bunkering operation 
Journal of Offshore Mechanics and Arctic Engineering

\begin{tabular}{|c|c|c|c|c|c|c|c|c|c|}
\hline \multicolumn{2}{|r|}{ HAZID Target } & \multicolumn{4}{|c|}{ FLPP Operation - LNG Bunkering } & \multicolumn{3}{|c|}{ Risk Index } & Recommendation \\
\hline 1 & Structural Impact & Collision & Harsh weather condition & $\begin{array}{l}\text { Hull damage, system } \\
\text { damage (bunkering vessel } \\
\text { collision) } I \\
\text { Personal iniury (falling) }\end{array}$ & $\begin{array}{l}\text { Double hull design (side), } \\
\text { Fender arrangement }\end{array}$ & 2 & 2.5 & 4.5 & $\begin{array}{l}\text { Establishing operational } \\
\text { guideline for bunkering }\end{array}$ \\
\hline 4 & Structural Impact & Collision & Miscommunication & $\begin{array}{l}\text { Hull damage, system } \\
\text { damage (bunkering vessel } \\
\text { collision) / } \\
\text { Personal iniury (fallina) }\end{array}$ & $\begin{array}{l}\text { Double hull design (side), } \\
\text { Fender arrangement }\end{array}$ & 2 & 2 & 4 & $\begin{array}{l}\text { Establishing operational } \\
\text { guideline for bunkering }\end{array}$ \\
\hline 7 & Operational & Human error & Manifold unlocking & Personnel injury \&r fatality & - & 2 & 3 & 5 & Visual indicator \\
\hline 8 & Operational & Human error & $\begin{array}{l}\text { Personnel misposition in } \\
\text { cargo tank }\end{array}$ & Personnel Fatality & - & 1 & 3 & 4 & $\begin{array}{l}\text { Operational guideline / } \\
\text { Safety moment }\end{array}$ \\
\hline \multicolumn{10}{|c|}{ Drying } \\
\hline 11 & Operational & Human error & \begin{tabular}{|l|} 
Incomplete drying process (= \\
more moisture condition \\
than criteria)
\end{tabular} & $\begin{array}{l}\text { LNG feed pump damage due } \\
\text { to icing / } \\
\text { Generator efficiency } \\
\text { decrease }\end{array}$ & e & 2 & 2 & 4 & $\begin{array}{l}\text { Manual samipling / } \\
\text { Operational guideline }\end{array}$ \\
\hline 14 & Operational & Human error & $\begin{array}{l}\text { Piping insulation damage } \\
\text { during construction, } \\
\text { transportation, installation }\end{array}$ & $\begin{array}{l}\text { Personnel injury (cryogenic) } / \\
\text { Low perfomance due to icing } \\
\text { in piping }\end{array}$ & 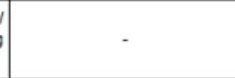 & 3 & 3 & 6 & Visual inspection \\
\hline 16 & Process Hazard & $\begin{array}{l}\text { Release of } \\
\text { inventory }\end{array}$ & $\begin{array}{l}\text { LN2 leakage (piping leak or } \\
\text { coupling \& fastner failure) }\end{array}$ & $\begin{array}{l}\text { Personnel injury (cryogenic) / } \\
\text { Structural damage } \\
\text { (cryogenic) }\end{array}$ & / & 1.5 & 3.5 & 5 & $\begin{array}{l}\text { Flange Management System } \\
\text { (FMS) procedure }\end{array}$ \\
\hline \multicolumn{10}{|c|}{ LNG Loading } \\
\hline 19 & Process Hazard & $\begin{array}{l}\text { Release of } \\
\text { inventory }\end{array}$ & $\begin{array}{l}\text { LNG leakage (piping leak or } \\
\text { coupling \& fastner failure) }\end{array}$ & \begin{tabular}{|l} 
Personnel injury I \\
Structural damage / \\
Fire
\end{tabular} & $\begin{array}{l}\text { (Active Fire Protection) } \\
\text { AFP } \\
\text { (e.g. fire water system, ... }\end{array}$ & 1.5 & 4 & 5.5 & $\begin{array}{l}\text { Bund/(for LNG leakage) } \\
\text { FMS I } \\
\text { Insulation (cryogenic\&fire) }\end{array}$ \\
\hline 20 & System Failure & $\begin{array}{l}\text { Measurement } \\
\text { system }\end{array}$ & Level transmitter failure & Overfilling - tank overpressure & $\cdot$ & 1.5 & 3.5 & 5 & Additional transmitter \\
\hline 22 & Structural impact & Fatigue & Mooring failure & $\begin{array}{l}\text { Hose connection failure I } \\
\text { LNG leakage \& Fire I } \\
\text { Personnel injury \& fatality }\end{array}$ & $\begin{array}{l}\text { Emergency break away } \\
\text { coupling I } \\
\text { AFP }\end{array}$ & 2 & 3 & 5 & - \\
\hline
\end{tabular}

Fig. 11 Categorized and ranked HAZID worksheet relevant to the LNG bunkering operation

OMAE-19-1002, Kim, 32 


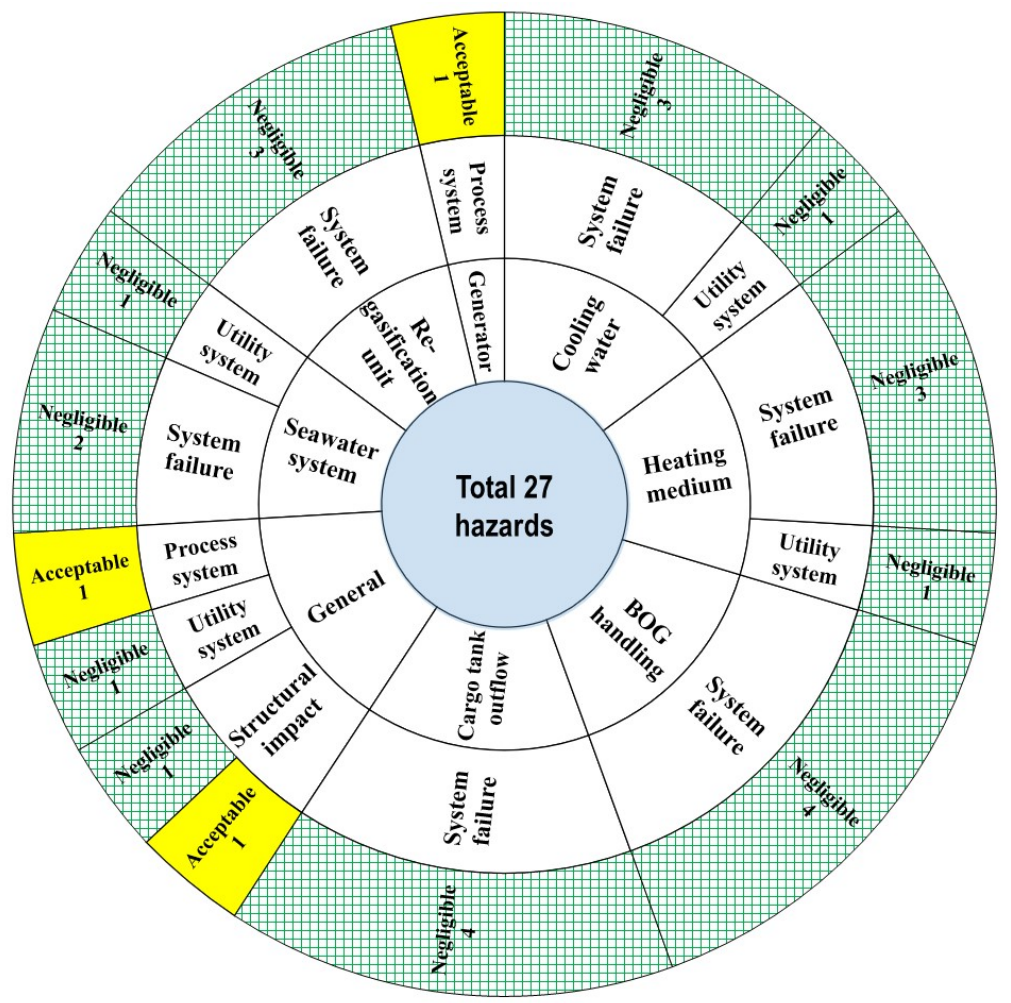

\#H Negligible risk Conditionally acceptable risk Intolerable risk

System failure (19)

- Mechanical failure or any safety system malfunction

Utility system (4)

- Loss of utility flow

- Utility system failure

Structural impact (2)

- Collision between a passing vessel and the plant

- Dropped-object during the normal operation

Process system (2)

- Release of process inventory during the operation

Fig. 12 Detail categorized hazards and risk levels relevant to the plant normal operation 
Journal of Offshore Mechanics and Arctic Engineering

\begin{tabular}{|c|c|c|c|c|c|c|c|c|c|}
\hline \multicolumn{2}{|r|}{ HAZID Target } & \multicolumn{4}{|c|}{ FLPP Operation - Normal Operation } & \multicolumn{3}{|c|}{ Risk Index } & \multirow[b]{2}{*}{ Recommendation } \\
\hline No. & Guidewords & Description & Possible Cause & Consequence & Existing Safety Measures & Freq. & Conseq. & Risk & \\
\hline \multicolumn{10}{|c|}{ General } \\
\hline 2 & Process Hazard & Release of inventory & Piping rupture, leakage & $\begin{array}{l}\text { Cryogenic leak (NG/LNG) / } \\
\text { Fire \& explosion / } \\
\text { Personnel fatality }\end{array}$ & $\begin{array}{l}\text { AFP, Shut-down valve (SDV) / } \\
\text { Inherent safety design }\end{array}$ & 1.5 & 3.5 & 5 & $\begin{array}{l}\text { FMS procedure / } \\
\text { Safety studies (dispersion, fire, } \\
\text { vent, etc.) }\end{array}$ \\
\hline 4 & Structural Impact & Dropped-object & $\begin{array}{l}\text { Misoperation during process } \\
\text { equipment handling }\end{array}$ & $\begin{array}{l}\text { Personnal injury / } \\
\text { Cable \& Piping damage }\end{array}$ & - & 2.5 & 3 & 5.5 & $\begin{array}{l}\text { Operational guideline / } \\
\text { Structural barrier }\end{array}$ \\
\hline \multicolumn{10}{|c|}{ 9001-000-PRO-PFD-0002 (LNG Storage Tank \& FEED Pump) } \\
\hline- & - & - & - & - & - & - & - & - & - \\
\hline \multicolumn{10}{|c|}{ 9001-000-PRO-PFD-0003 (Regasification Unit) } \\
\hline- & - & - & - & - & - & - & - & - & - \\
\hline \multicolumn{10}{|c|}{ 9001-000-PRO-PFD-0005 (BOG Handling System) } \\
\hline- & - & - & - & - & - & - & - & - & - \\
\hline \multicolumn{10}{|c|}{ 9001-000-PRO-PFD-0006 (Dual Fuel Engine Generator Electricity Supply) } \\
\hline 18 & Process Hazard & Rupture, leakage & Flammable leak from GVU & Fire \& Explosion & $\begin{array}{l}\text { AFP / } \\
\text { Structural barrier (enclosure) }\end{array}$ & 1.5 & 3.5 & 5 & - \\
\hline \multicolumn{10}{|c|}{ 9001-000-PRO-PFD-0004 (Utility - Glycol) } \\
\hline- & - & - & - & - & - & - & - & - & - \\
\hline \multicolumn{10}{|c|}{ 9001-000-PRO-PFD-0007 (Seawater Pretreatment System) } \\
\hline- & - & - & - & - & - & - & - & - & - \\
\hline \multicolumn{10}{|c|}{ 9001-000-PRO-PFD-0008 (Cooling Water System) } \\
\hline - & - & - & - & - & - & - & - & - & - \\
\hline
\end{tabular}

Fig. 13 Categorized and ranked HAZID worksheet relevant to the plant normal operation

OMAE-19-1002, Kim, 34 
Journal of Offshore Mechanics and Arctic Engineering

Table 1. Principal dimension of the floating power plant hull structure.

\begin{tabular}{|l|c|}
\hline Length Overall (L.O.A.) & Approx. $70.0 \mathrm{~m}$ \\
\hline Breadth (moulded) & Approx. $30.0 \mathrm{~m}$ \\
\hline Depth to upper deck (moulded) & Approx. $9.0 \mathrm{~m}$ \\
\hline Design draught (moulded) & Approx. $3.5 \mathrm{~m}$ \\
\hline
\end{tabular}

OMAE-19-1002, Kim, 35 
Journal of Offshore Mechanics and Arctic Engineering

Table 2. Detail target operation modes of each HAZID session.

a. Floating power plant LNG bunkering operation

\begin{tabular}{|c|l|c|l|}
\hline No. & \multicolumn{1}{|c|}{ Operation mode (Remark) } & No. & \multicolumn{1}{|c|}{ Operation mode (Remark) } \\
\hline 1 & Berthing (ship to ship mooring) & 2 & Hose connecting (crane connection) \\
\hline 3 & Drying (air into cargo tank) & 4 & Inerting (N2 into cargo tank) \\
\hline 5 & Cool-down (LN2 into cargo tank) & 6 & LNG transfer (LNG into cargo tank) \\
\hline
\end{tabular}

b. Floating power plant normal operation (Power generation)

\begin{tabular}{|c|l|c|l|}
\hline No. & \multicolumn{1}{|c|}{ Operation mode (Remark) } & No. & \multicolumn{1}{|c|}{ Operation mode (Remark) } \\
\hline 1 & General & 2 & Cargo tank outflow (process flow) \\
\hline 3 & Regasification unit (process flow) & 4 & BOG handling system (process flow) \\
\hline 5 & Power generator (process flow) & 6 & Heating medium (utility flow) \\
\hline 7 & Seawater system (utility flow) & 8 & Cooling water system (utility flow) \\
\hline
\end{tabular}

c. Floating power plant general design: General layout drawing 
Journal of Offshore Mechanics and Arctic Engineering

Table 3. Guideword lists of the HAZID study.

\begin{tabular}{|c|l|l|}
\hline No. & \multicolumn{1}{|c|}{ Guidewords } & \multicolumn{1}{c|}{ Description } \\
\hline 1 & General design & Expected hazards relevant to the general plant layout design \\
\hline 2 & Environmental & Harsh weather (wind, wave, etc.), Disaster (typhoon, tsunami, etc.) \\
\hline 3 & Process system & $\begin{array}{l}\text { Process system failure (loss of containment, mechanical failure, } \\
\text { etc.) }\end{array}$ \\
\hline 4 & Utility system & Utility system failure (loss of containment, mechanical failure, etc.) \\
\hline 5 & Fire \& Explosion & External fire \& explosion and non-Process fire \\
\hline 6 & Structural impact & Collision, Sloshing, Dropped-object, Fatigue, Corrosion, etc. \\
\hline 7 & System failure & $\begin{array}{l}\text { Failure of ballast system, measuring equipment, safety function, } \\
\text { etc. }\end{array}$ \\
\hline 8 & Operational & Human error or Miss-operation \\
\hline
\end{tabular}

OMAE-19-1002, Kim, 37 
Journal of Offshore Mechanics and Arctic Engineering

Table 4. Risk matrix for the evaluation and ranking of the risk level in the HAZID study.

\begin{tabular}{|c|c|c|c|c|c|}
\hline & \multicolumn{4}{|c|}{ Consequence index } \\
\hline \multicolumn{2}{|c|}{ Frequency index / Description } & 1 & 2 & 3 & 4 \\
\hline 1 & Hardly occurred & 2 & 3 & 4 & 5 \\
\hline 2 & Unlikely & 3 & 4 & 5 & 6 \\
\hline 3 & Possible & 4 & 5 & 6 & 7 \\
\hline 4 & Frequent & 5 & 6 & 7 & 8 \\
\hline
\end{tabular}

OMAE-19-1002, Kim, 38 
Journal of Offshore Mechanics and Arctic Engineering

Table 5. Consequence indices of the HAZID study.

\begin{tabular}{|c|l|l|l|}
\hline \multirow{2}{*}{ Index } & \multicolumn{3}{|c|}{ Category \& Description } \\
\cline { 2 - 4 } & Personnel impact & Structure impact & \multicolumn{1}{|c|}{ Asset impact } \\
\hline 1 & Single injury & Minor equipment damage & Less than USD 150,000 \\
\hline 2 & Multiple injury & Major equipment damage & Shutdown (about 1week) \\
\hline 3 & Single fatality & Global damage & Shutdown (less than 3 weeks) \\
\hline 4 & Multiple fatality & Total plant loss & Shutdown (more than 3 weeks) \\
\hline
\end{tabular}

OMAE-19-1002, Kim, 39 
Journal of Offshore Mechanics and Arctic Engineering

Table 6. Frequency indices of the HAZID study.

\begin{tabular}{|c|l|l|r|}
\hline Index & \multicolumn{2}{|c|}{ Description } & Frequency \\
\hline 1 & Hardly occurred & Hardly occurred in similar systems or industries & 0.000001 \\
\hline 2 & Unlikely & Occur once per 10,000 years & 0.0001 \\
\hline 3 & Possible & Occur once per 100 years & 0.01 \\
\hline 4 & Frequent & Occur once or more than once per year & $>1$ \\
\hline
\end{tabular}

OMAE-19-1002, Kim, 40 